\title{
The Effect of Phosphorus in Nitrogen Fixation in Legumes
}

\author{
Reem M Hussain* \\ Department of Crop Field, Huazhong Agricultural University, PR China
}

Submission: March 06, 2017; Published: March 21, 2017

"Corresponding author: Reem M Hussain, Department of Crop Field, State Key Lab of Agriculture Microbiology, College of Plant Science and Technology, Huazhong Agricultural University, Wuhan 430070, Hubei, PR China, Fax: +963-41-445296; Email: rmrommh@hotmail.com; reemhussain@webmail.hzau.edu.cn

\section{Abstract}

Through the years, agriculturists have explored different ways to help the growth and development of plants, increase crop production, and address farming sustainability. This is crucial since in today's age, global demands from consumers are continuously increasing and the farming industry is becoming more aggressive in searching for ways to improve crop production. However, looking back in history, there are methods that have been proven effective in soil cultivation. Our ancestors figured out how growing legumes benefits the soil making it more fertile for the next crops.

\section{Introduction}

The practice of growing legumes has always been a part of crop rotations dating back to the ancient times [1]. Legumes play an important role in sustainable farming because of its ability to increase soil fertility [2]. Legumes have a mutual symbiotic relationship with some bacteria in the soil that can improve levels of nitrogen in the atmosphere [3]. Legumes are nodulated plants that play an important role in nitrogen fixation [4].

Nitrogen fixation is a process of changing atmospheric nitrogen to ammonia or other molecules needed by living organisms [5]. Nitrogen fixation is an important process for agriculture and for the manufacturing of fertilizers [3]. In legumes, atmospheric nitrogen $\left(\mathrm{N}_{2}\right)$ fixation happens in the nodules [6]. Nodules grow in the roots that are produced by $\mathrm{N}_{2}$-fixing rhizobial bacteria [6]. Most of these bacteria belong to the genera of Bradyrhizobium, Mesorhizobium, Rhizobium and Sinorhizobium [7].

While nitrogen fixation is a sustainable way of producing nitrogen $(\mathrm{N})$ which is important in making chemical fertilizers, several factors cause some limitations [8]. Some biotic and abiotic factors affect the mutual interaction between legumes and their microsymbiont partner $[8,9]$. Legume productions are negatively impacted by several factors such as drought [8], low $\mathrm{pH}$ levels [10], salinity [11], heavy metals [12], extreme temperatures and low nutrient availability on the soil where legumes are grown [13]. This also proves how climate change is gravely affecting legume production. Decrease in the availability of phosphorus in soil also has an impact in legume production [14].

The mini-review focuses on the Various researches that have looked into this situation and conducted tests to prove the relationship between phosphorus availability and legume growth and production.

\section{Phosphorus}

Phosphorus (P) plays a vital role in the growth and development of plants. It is needed in the molecular structure of plants and it facilitates transformation of energy and regulation of several enzymatic activities as well [15]. Here are some molecules that contain phosphorus: Nucleic Acids, proteins, lipids, sugars and adenylate [16].

In adenylates, phosphorus is the main component required for most of the functions of plant cells [16]. Phosphorus is also essential in most metabolic processes that happen above the ground. These processes include: Energy generation, nucleic acid synthesis, photosynthesis, respiration, glycolysis, membrane synthesis and integrity, enzymatic activation or inactivation, redox reactions, signaling and carbohydrate metabolism [17].

Therefore, inadequate phosphorus in soil gravely affects the growth and development of plants. For instance, lack of phosphorus affects a leaf's development and ability to carry out photosynthesis 
therefore causing the plant not to produce sufficient food to support optimal growth [14].

Carbon absorption and distribution between plant's shoots and its parts underground can also be affected by inadequate supply in phosphorus. Since development and metabolism above the ground are connected to symbiotic tissues, low phosphorus supply can negatively affect the functions and growth of nodules because certain amount of phosphorus is needed to carry out symbiotic nitrogen fixation [18].

There are many evidences that prove how legumes require more phosphorus for nitrogen fixation to achieve maximum function. More phosphorus is required in legumes since phosphorus is needed in energy transformation in nodules [19].

Research proved that nodulated legumes need more phosphorus than non-symbiotic plants that grows solely on a mineral nitrogen source. The direct relationship between nitrogen fixation and phosphorus content on nodules simply proves how important phosphorus is to legumes $[19,20]$. $\mathrm{N}_{2}$-fixing legumes that are grown with inadequate phosphorus did not grow well because nitrogen fixation on bacteroids, ammonium absorption of amino acids and ureides in the plant cell of nodules are not enough to support plant growth [18]. These processes require more phosphorus in the transfer of energy which occurs in nodule functioning [19]. In addition to this, the phosphorus required for mitochondrial and symbiosome membrane synthesis during nodule development increases $\mathrm{N}_{2}$-fixing legume's demand for phosphorus even more [19].

\section{Conclusion}

Legumes are dependent on adequate phosphorus content in the soil. However, farm soils nowadays do not have enough phosphorus to help nitrogen fixation in legumes. This is one of the challenges we face globally making it more difficult to grow plants naturally.

To address a sustainable way of growing crops and saving the soil from complete nutrient depletion, agriculturists should consider these things. As of now, most farms are dependent on mineral nitrogen and phosphorus due to the soil's deficiency for these minerals.

Unfortunately, as projected in many scientific researches, there will also be a significant decrease in rock phosphates, which is the main source of phosphorus in fertilizers, in 30-50 years. Currently, $90 \%$ of phosphorus in fertilizers comes from mined rock phosphate. Therefore, a decrease in the growth and production of legumes will be affected significantly by the availability of phosphorus in the years to come. One cannot underestimate the impact of a deficiency in a single element or mineral in the agricultural industry since it is proven that minerals and organic processes work hand in hand.

\section{References}

1. John L, Sheaffer C, Moncada K (2010) Soil Fertility. Risk Management Guide for Organic Producers (Report).

2. Mugendi DN, Waswa BS, Mucheru-Muna MW, Kimetu JM, Palm C (2011)
Fighting Poverty in Sub-Saharan Africa: The Multiple Roles of Legumes in Integrated Soil Fertility Management. pp. 151-173.

3. Jim D (2015) The Nitrogen cycle and Nitrogen fixation. Institute of Cell and Molecular Biology, The University of Edinburgh, UK.

4. Schulze J (2004) How are nitrogen fixation rates regulated in legumes? J Plant Nutr Soil Sci 167(2): 125-137.

5. Badri DV, Weir TL, Van Der Lelie D, Vivanco JM (2009) Rhizosphere chemical dialogues: plant-microbe interactions. Curr Opin Biotechnol 20(6): 642-650.

6. Broughton WJ, Zhang F, Perret X, Staehelin C (2003) Signals exchanged between legumes and Rhizobium: agricultural uses and perspectives. Plant Soil 252(1): 129-137.

7. Fauvart M, Michiels J (2008) Rhizobial secreted proteins as determinants of host specificity in the rhizobium-legume symbiosis. FEMS Microbiol Lett 285(1): 1-9.

8. Andres JA, Rovera M, Guiñazú LB, Pastor NA, Rosas SB (2012) Interactions between legumes and rhizobia under stress conditions. In: Dinesh KM (Ed.), Bacteria in Agrobiology: Stress Management. Springer-Verlag, Berlin, Germany, pp. 77-94.

9. Lira Junior MA, Lima AST, Arruda JRF, Smith DL (2005) Effect of root temperature on nodule development of bean, lentil and pea. Soil Biol Biochem 37: 235-239.

10. Lin MH, Gresshoff PM, Ferguson BJ (2012) Systemic regulation of soybean nodulation by acidic growth conditions. Plant Physiol 160(4): 2028-2039.

11. Abd-Alla MH, El-Enany AWE, Bagy MK, Bashandy SR (2013) Alleviating the inhibitory effect of salinity stress on nod gene expression in Rhizobium tibeticum- fenugreek (Trigonella foenum graecum) symbiosis by isoflavonoids treatment. J Plant Int 9: 275-284.

12. Schue M, Fekete A, Ortet P, Brutesco C, Heulin T, et al. (2011) Modulation of metabolism and switching to biofilm prevail over exopolysaccharide production in the response of Rhizobium alamii to cadmium. PLoS ONE 6: e26771.

13. Wei M, Takeshima K, Yokoyama T, Minamisawa K, Mitsui H, et al. (2010) Temperature-dependent expression of type III secretion system genes and its regulation in Bradyrhizobium japonicum. Mol Plant Microbe Int 23(5): 628-637.

14. Doi Sulieman S, Tran LS (2015) Phosphorus homeostasis in legume nodules as an adaptive strategy to phosphorus deficiency. Plant Sci 239: $36-43$.

15. Schulze J, Temple G, Temple SJ, Beschow H, Vance CP (2006) Nitrogen fixation by white lupin under phosphorus deficiency. Ann Bot 98(4): 731-740.

16. Zhang Z, Liao H, Lucas WJ (2014) Molecular mechanisms underlying phosphate sensing, signaling, and adaptation in plants. J Integr Plant Biol 56(3): 192-220.

17. Vance CP, Uhde-Stone C, Allan DL (2003) Phosphorus acquisition and use: critical adaptations by plants for securing a nonrenewable resource. New Phytol 157(3): 423-447.

18. Hernandez G, Valdes-Lopezn M, Ramirez M, Goffard N, Weiller G, et al. (2009) Global changes in the transcript and metabolic profiles during symbiotic nitrogen fixation in phosphorus-stressed common bean plants. Plant Physiol 151: 1221-1238.

19. Rotaru V, Sinclair TR (2009) Interactive influence of phosphorus and iron on nitrogen fixation by soybean. Environ Exp Bot 66: 94-99.

20. Cabeza RA, Liese R, Lingner A, von Stieglitz I, Neumann J, et al. (2014) RNA-seq transcriptome profiling reveals that Medicago truncatula nodules acclimate N2 fixation before emerging P deficiency reaches the nodules. J Exp Bot 65: 6035-6048. 
(C) Commons Attribution 4.0 License BY DOI: 10.19080/ARTOAJ.2017.04.555654

\section{Your next submission with Juniper Publishers} will reach you the below assets

- Quality Editorial service

- Swift Peer Review

- Reprints availability

- E-prints Service

- Manuscript Podcast for convenient understanding

- Global attainment for your research

- Manuscript accessibility in different formats

( Pdf, E-pub, Full Text, Audio)

- Unceasing customer service

Track the below URL for one-step submission https://juniperpublishers.com/online-submission.php 